\title{
Subsidies in Chilean Public Utilities ${ }^{1}$
}

\author{
Pablo Serra ${ }^{2}$
}

\section{Universidad de Chile}

${ }^{1}$ The author is grateful to Alejandro Medina, Ministry of Economics, Miguel Pantoja, Ministry of Public Works, Rubén Muñoz, National Energy Commission, and Daniela Vergara, Under-secretariat of Telecommunications, for providing data and their time for interviews. I also thank Andrés Gómez -Lobo for pointing to very useful literature. This article was written for the World Bank Institute, but it does not necessarily reflect the views and policies of the Bank.

${ }^{2}$ Centro de Economía Aplicada, Departamento de Ingeniería Industrial, Universidad de Chile. 


\title{
Subsidies in Chilean Public Utilities
}

\begin{abstract}
This paper makes an analysis of subsidies in Chile's public utilities. Rates rebalancing have practically eliminated cross subsidies, and current programs are funded from the national budget. Over the last decade in particular, significant efforts have been made to extend public services to rural populations, and a consumption subsidy for potable water currently benefits $17 \%$ of the population.

The Chilean experience shows it is possible to design subsidies targeted to the poor that do not cause deadweight losses, and at relatively low cost to the State. The elimination of cross subsidies has facilitated competition in some public services. Moreover, putting rural infrastructure projects out to public tender, whenever possible, has made it possible to substantially reduce government expenditure
\end{abstract}

\section{Introduction}

The purpose of this paper is to analyze Chile's utility subsidization programs. These include investment subsidies in all utilities, which aim to develop rural infrastructure by providing supplementary funding for projects that are socially but not privately profitable. In fact, the maximum subsidy may not be greater than either the (negative) private net present value (NPV) or the total investment. Thus, users should be able to finance the operation, maintenance, and administration of the service. Normally it is the potential beneficiaries of a project that request a subsidy, although occasionally the initiative comes from local or central authorities. Since resources are limited, one criterion used to prioritize projects has been the social NPV per peso of subsidy required.

There is also a targeted consumption subsidy for both urban and rural households in the case of drinking water, the consumption of which has always been subsidized in Chile. Formerly, water the charges were below the cost of providing the service and there was no incentive to collect bad debts. Thanks to this policy, however, for many years now the coverage of drinkable water has been very extensive, with $98 \%$ of urban homes and $76 \%$ of 
households in rural concentrated zones connected to potable water services by 1987 (see Ale, 1990). However, the introduction of cost-reflecting pricing rules in 1989 prior to privatization of the water companies, made it necessary to introduce an explicit consumption subsidy. This is targeted on the poorest $20 \%$ of the population, and subsidizes the first $15 \mathrm{~m}^{3}$ of monthly consumption by between $40 \%$ and $85 \%$. The subsidy rate is higher in tariff-zones where water charges are higher and the average income of the poorest $10 \%$ of the population is lower.

The subsidization of public utilities forms part of the government's social policy. Although subsidies represent a minor part of the country's social expenditure, it is legitimate to question whether the poor would not be better off receiving cash transfers. Opponents of specific subsidies argue that, with lump-sum transfers, beneficiaries can choose their consumption basket for themselves, thereby maximizing their utility. It is also claimed that specific subsidy programs have higher administrative costs than cash transfers do. In view of these claims, next we discuss the validity of subsidizing public utilities.

In the first place, utility subsidies are justified by the existence of positive externalities. Theory shows that private expenditure on goods that generate positive consumption externalities is likely to fall below the socially optimal level. There are clearly significant externalities in the consumption of drinkable water and sewerage services, as households without sanitary services are likely to be more prone to diseases, which are then transmitted to other families. Moreover, part of the cost of the illnesses arising from the lack of sanitation is borne by the public health services that care for vulnerable households. A different sort of externality exists in telecom services, namely network economies. When a new user joins a network, this benefits not only the user concerned but also the existing subscribers whose communication possibilities also expand. 
A second reason for subsidizing utilities is the substantial scale economies involved in providing public services, especially in low-density rural areas. With a regulated or agreed price, revenues might be insufficient to cover total costs, yet the project could well be socially profitable if the consumer surplus at the given price exceeds the social costs. One alternative would be to allow the price to rise until the private NPV of the project turned positive, but, given the low density of demand in rural areas, scale economies are large, and the price that makes the investment privately profitable could be much higher than the marginal cost of production. As a result, adopting this price could cause significant efficiency losses. Moreover, a price that allows the investment to be fully financed might not even exist.

This problem would be solved by seeking an initial contribution from the beneficiaries, or by applying a two-part tariff consisting of a per-unit charge equal to marginal cost plus a standing charge that allows the service to be financed. In order to finance the investment, people with greater willingness to pay might have to make a larger contribution; however, all the incentives for free riding are present in such a situation. In fact, in the case of the rural electrification subsidy, interested parties can make voluntary contributions, which by lowering the subsidy required would have the effect of increasing the priority assigned to the project. However, in practice such contributions have not been forthcoming, and, in any event, the transaction costs of eliciting potential beneficiaries' willingness to pay could be so high that a subsidy becomes a more efficient solution.

A third reason for subsidizing utilities is that their consumption by poor households may enter directly into the social utility function. If such is the case, then maximizing social welfare implies subsidizing certain goods and services and not simply transferring un- 
earmarked money to people in need. Harberger (1978) argues that free education, subsidized medical care; food and housing for the poor are all standard fixtures in today's world, in developed and developing countries alike. Attempts to convert such subsidies into their cash equivalent regardless of how the cash might be spent have everywhere faltered and failed. Harberger believes that this might reflect the value systems of our societies. For instance, he argues, a look at intra-family transfers shows that these seem to be aimed more at financing specific expenditures or "needs", rather than representing a systematic sharing of wealth through cash transfers. The success of initiatives to assist people that have suffered misfortune is another indication of the same phenomenon. Thereby, it is easier for low-income people to articulate their demands in terms of specific goods and services, given their receptivity in society, than justify demands for higher income.

Waddams Price (1999) believes that the public perceives utilities as services that are necessary for life, thereby challenging the idea that these are services that consumers freely choose whether to buy. Moreover, society seems to have a special regard for the needs of consumers living in rural and isolated areas, as illustrated by the strong impact of TV reports describing the isolation of remote areas of the country and how their inhabitants endure medical and other emergencies. Doble, Markou and Waddams Price (1998) report that $73 \%$ of respondents in a sample-survey of 1,685 people in the UK believe that water should be provided at a subsidized rate to households who are unable to afford it for themselves. The corresponding figures for electricity and telephony are $67 \%$ and 53\%, respectively.

Sometimes the reasons underlying programs to subsidize certain goods or services are more debatable, but these are normally not made explicit. One such is paternalism: the 
State knows best how what to spend resources on, especially when these cater to the needs of poor households with little education. To the above could be added the desire to populate remote areas of the country for reasons of national sovereignty. In brief, there are a variety of reasons justifying the use of specific subsidies, for which reason the rest of this article takes their continued existence as given and focuses on discussing their effectiveness.

Over the last five years in particular, Chile has made great efforts to extend public services to rural populations, and programs to subsidize rural infrastructure have benefited numerous families. The proportion of electrified rural homes rose from $57 \%$ in 1994 to $75 \%$ in 1999, at a total cost on the order of US\$ 130 million, and the aim is to have reached all rural households by 2005. Drinking water coverage in concentrated rural areas grew from $81 \%$ in 1994 to $93 \%$ in 1998 , with the State contributing US\$ 110 million to this end; projections are for $98 \%$ of the concentrated rural population to have running water by the end of the year 2000. In addition, $80 \%$ of the rural population will have access to public telephones by 2000 , compared to just $10 \%$ in 1995 , with the corresponding program having spent US\$ 20 million in its first five years of operation. Lastly, the drinking water consumption subsidy benefits $17 \%$ of the population, at an annual cost of about US\$ 30 million.

The rest of this paper is organized as follows: section 2 describes the drinking water consumption subsidy. The following sections provide an overview of subsidies supporting rural investment in potable water, electricity and telecommunications, respectively. Section 6 analyzes the efficacy of subsidy programs, and the final section draws conclusions. 


\section{Consumption subsidy in water and sanitation services ${ }^{3}$}

In the late 1980s, water rates were on average less than half of what was needed to finance provision of the service, with prices covering less than $20 \%$ of outlays in regions with higher production costs. Tthis form of subsidy was highly inefficient (users were not confronted with the real cost of water services), and the benefits were greater among highincome families who consumed larger amounts. Prior to privatization, however, charges had to be raised so that the water companies could cover their costs. Unlike what happened with the other public services, the process that should have led to the privatization of the water companies was only started in the final stages of the military regime (1973-1989), and it could not be concluded before democracy was restored. The need to raise charges acted as a significant hindrance to the rapid transfer of sanitation companies to the private sector, as privatization accompanied by a substantial price hike would have been politically unpopular.

Sectoral modernization had begun in 1977, with the creation of the Servicio Nacional de Obras Sanitarias (Sendos) at the Ministry of Public Works. This service absorbed several agencies belonging to different ministries and made it possible to downsize the workforce from 10,000 to 3,000 . Apart from regulatory responsibilities for the whole sector, Sendos was put in charge of providing water services in the regions. In the same year, water companies were set up in the Santiago Metropolitan Region (Emos) and in the Vth Region (Esval), based on pre-existing small companies. Emos and Esval were also related to the State through the Ministry of Public Works. The creation of Sendos represented a significant change of approach. Until then, the financing of the service was

\footnotetext{
${ }^{3}$ This section builds on Blanlot (1999) and Mideplan (1999).
} 
not one of the government agencies' objectives, which led among another things to a total lack of interest in chasing bad debts. Without changing water rates, Sendos was able to significantly increase water company revenues merely by being more energetic in collecting arrears.

In 1988, a new regulatory framework was set up for the sector, closely matching its electricity sector counterpart. The new rate system allows for the self-financing of efficient firms. Pricing zones with relatively homogeneous costs were also established. The new pricing system was introduced gradually as from 1990, and charges rose by an average of 90\% in real terms between 1990 and 1994, although by this time the rate adjustment process was still not complete in all regions. The price rise was steeper in areas with higher costs, exceeding 500\% in some cases, and by 1998 average regional water rates ranged from US $\varnothing$ 43 to USф 121 per $\mathrm{m}^{3}$ of consumption. Arrears were cut from $7.9 \%$ in 1990 to $2.9 \%$ in 1994 , as a result of a more commercial approach, whereby the subsidy policy gave incentives for prompt payment, and firms were given faculties to suspend services to customers in arrears. In 1994 the average rate of return on capital among public water companies was $6.3 \%$, with the profitability of individual firms ranging between $-4.5 \%$ and $13.2 \% .^{4}$

Antedating the rate hike, in February1989 a demand subsidy for water and sewerage services was introduced. This was targeted on the poorest urban families, defined initially as the poorest $20 \%$ in each region. Potential beneficiaries had to apply for the subsidy in their municipality, which entailed filling out a socioeconomic evaluation form (SEF), unless they had already done this for other purposes. Eligibility criteria included having no arrears with

\footnotetext{
${ }^{4}$ In 1998 the rate of return on equity for the public sanitation companies ranged from -6.9 percent to 11.9 percent with an average of 6,6 percent.
} 
the water company, or having negotiated payment thereof, and consumption of less than $20 \mathrm{~m}^{3}$ per month. By August 1991 the subsidy was only reaching $14.1 \%$ of estimated potential beneficiaries. The government's take on this situation was that the eligibility criteria were too stringent, and this led to their relaxation. ${ }^{5}$ In 1991 a legal amendment abolished the requirement of consuming less than $20 \mathrm{~m}^{3}$ of water per month, suspended the no-debt requirement till the end of the year, authorized water companies to submit applications on behalf of their clients until December, ${ }^{6}$ and extended the subsidy to families sharing a house and to housing compounds sharing a water meter. By the end of the year, $42 \%$ of estimated potential beneficiaries were being subsidized.

The subsidy program is funded from the annual budget of the central government, which allocates resources to regional governments. These, in turn, distribute the available funds among their municipalities. In the event of a municipality not having sufficient resources to finance all eligible applications, it has to assign the available funds between applicants according to their SEF point scores. The municipalities pay the subsidies directly to the water companies, and customers are billed for the difference.

Initially the subsidy was equal to $50 \%$ of the bill, up to a consumption of $10 \mathrm{~m}^{3}$. In August 1991 a subsidy range was introduced, from a minimum $40 \%$ to a maximum $75 \%$ of the monthly bill for consumption up to $15 \mathrm{~m}^{3}$. The purpose of this amendment was to provide greater relief in regions where rate rebalancing would lead to larger price increases. Regionally differentiated subsidies were implemented for the first time in 1993. In the three regions where potable water is dearest (Regions I, II, XI), the subsidy was raised to 75\%,

\footnotetext{
${ }^{5}$ The initial lack of interest in applying for the subsidies could also be explained by the gradualness of the price increase, which made it less urgent to apply for the subsidy at the outset
} 
while in the regions where it is cheapest (VIII, XII, and Metropolitan) it was held at 50\%; the subsidy for intermediates zones was set at $60 \%$.

In 1994 the legislation was amended once again to include economic need as a determinant of the subsidy; the range was widened to $25 \%-85 \%$, and maximum subsidizable consumption was increased from $15 \mathrm{~m}^{3}$ to $20 \mathrm{~m}^{3}$. This amendment also authorized setting more than one subsidy rate within a region. With a view to concentrating resources in regions with higher poverty indices, the population target was redefined as the poorest $20 \%$ nationwide, instead of the previous regional definition. The law also extended the subsidy to rural consumers as from 1995 , to cover $50 \%$ of the bill for the first $15 \mathrm{~m}^{3}$ of water consumed.

In 1996, the socioeconomic condition of the region and the rate zone to which the beneficiary belonged began to be used in calculating the subsidy rate, although the subsidizable consumption limit was maintained at $15 \mathrm{~m}^{3}$. The subsidy rate varied from $82 \%$ in rate zone 2 of Region I and 50\% in the Metropolitan Region. Political considerations made it unfeasible to reduce the initial subsidy rate of 50\% in low-cost areas. The absolute difference between subsidy amounts is greater still: in 1998, the average monthly subsidy varied between $\mathrm{Ch} \$ 9,305$ and $\mathrm{Ch} \$ 1,337$. The average monthly subsidy in urban areas is on the order of $\mathrm{Ch} \$ 2,800$, considerably above the rural equivalent of $\mathrm{Ch} \$ 400$.

The long-run goal is to comply with the World Health Organization (WHO) recommendation that families should spend no more than $5 \%$ of their income on water and sanitation services. As a national average, the after-subsidy bill for a consumption of $15 \mathrm{~m}^{3}$ accounts for $5.5 \%$ of the average income earned by a family in the tenth decile, but this figure varies widely from region to region. The bill for consuming $15 \mathrm{~m}^{3}$ of water ranges

\footnotetext{
${ }^{6}$ The possibility that companies could submit applications for their customers was made permanent in 1994.
} 
from $2.8 \%$ to $11.9 \%$ of average family income in the first decile, depending on regional income and the pricing zone. For a family in the IXth Region with the average income of the lowest decile (Ch\$ 25,710 per month) and living in the second pricing zone, a consumption of $15 \mathrm{~m}^{3}$ would account for $34 \%$ of its income (Ch\$ 8,752). Since the subsidy rate for this zone is $65 \%$, the household would end up spending $11.9 \%$ of its income on water and sanitation services.

The subsidy program has been quite successful in several respects, firstly in reaching the target population. By the end of 1997 the number of urban subsidies stood at 443,953 , and rural subsidies totaled 61,435 ; as a result subsidies were covering $95 \%$ of total estimated potential beneficiaries (see Table 1). Most importantly, $72.8 \%$ of beneficiaries were in the poorest group as measured by their SEF scores. From the standpoint of results, despite the sharp rise in charges, the coverage of potable water did not decline, but actually increased. By $1998,99.3 \%$ of all urban families had running water, of which $17.4 \%$ were subsidized.

Another advantage of the new subsidy is its low cost compared to the previous system. In 1998, the funding allocated to the urban program totaled Ch\$ 15,479 million (excluding the administrative cost borne by the municipalities), plus $\mathrm{Ch} \$ 600$ million assigned to the rural subsidy program. This figure represents $31 \%$ of the net profits of State-owned water companies, in that year, which amounted to $\mathrm{Ch} \$ 49,452$ million. The average rate of return in State-owned water companies was 6.6\% in 1998, and in 1997 subsidies accounted for $6.3 \%$ of public water companies' total billings. ${ }^{7}$ This compares

\footnotetext{
${ }^{7}$ There is a sharp inter-regional variation in the relation between subsides and total billings, ranging from $18 \%$ in Region IX to $3 \%$ in the Santiago Metropolitan Region..
} 
favorably with the previous situation in which water providers were unable even to cover operating costs, and is mainly the result of subsidy targeting and setting limits on subsidized consumption.

Table 1: Water consumption subsidy: beneficiaries and subsidy amounts in 1998

\begin{tabular}{|c|c|c|c|c|c|}
\hline \multirow[b]{2}{*}{ Region } & \multicolumn{2}{|c|}{ Beneficiary users } & \multicolumn{2}{|l|}{ Subsidy } & \multirow{2}{*}{$\begin{array}{l}\text { Expenditure as a } \\
\% \text { of family } \\
\text { income }(\%)\end{array}$} \\
\hline & Number & $\%$ of population & $\begin{array}{l}\text { Average amount in } \\
\mathrm{Ch} \$\end{array}$ & $\%$ of bill & \\
\hline I & 19,096 & 21.1 & 7,247 & $\begin{array}{l}73 \\
82\end{array}$ & $\begin{array}{l}2.9 \\
2.9\end{array}$ \\
\hline II & 25,051 & 24.6 & 8,257 & $\begin{array}{l}80 \\
75\end{array}$ & $\begin{array}{l}2.8 \\
3.2\end{array}$ \\
\hline III & 17,147 & 30.5 & 6,172 & $\begin{array}{l}70 \\
75\end{array}$ & $\begin{array}{l}4.0 \\
7.5\end{array}$ \\
\hline IV & 21,902 & 18.4 & 4,209 & $\begin{array}{l}60 \\
62 \\
62\end{array}$ & $\begin{array}{l}5.5 \\
6.4 \\
6.7\end{array}$ \\
\hline $\mathrm{V}$ & 63,034 & 19.1 & 2,927 & $\begin{array}{l}60 \\
65 \\
60 \\
60 \\
60 \\
75\end{array}$ & $\begin{array}{l}4.3 \\
3.6 \\
4.4 \\
4.2 \\
3.8 \\
4.7\end{array}$ \\
\hline VI & 17,681 & 15.5 & 2,740 & $\begin{array}{l}60 \\
60\end{array}$ & $\begin{array}{l}6.0 \\
4.8\end{array}$ \\
\hline VII & 27,706 & 21.4 & 3,427 & $\begin{array}{l}60 \\
64 \\
72\end{array}$ & $\begin{array}{l}6.7 \\
7.3 \\
5.8\end{array}$ \\
\hline VIII & 63,925 & 22.0 & 3268 & $\begin{array}{l}60 \\
65\end{array}$ & $\begin{array}{l}5.7 \\
6.2\end{array}$ \\
\hline IX & 35,816 & 31.9 & 4,236 & $\begin{array}{l}60 \\
72 \\
60\end{array}$ & $\begin{array}{l}9.5 \\
11.9 \\
12.0 \\
\end{array}$ \\
\hline $\bar{X}$ & 25,883 & 24.6 & 3,731 & $\begin{array}{l}65 \\
65 \\
75 \\
\end{array}$ & $\begin{array}{l}7.8 \\
5.5 \\
5.9\end{array}$ \\
\hline XI & 6,002 & 35.2 & 5,389 & $\begin{array}{l}80 \\
75\end{array}$ & $\begin{array}{l}5.4 \\
3.8\end{array}$ \\
\hline XII & 6,255 & 18.1 & 3,759 & $\begin{array}{l}60 \\
60 \\
\end{array}$ & $\begin{array}{l}4.7 \\
4.7 \\
\end{array}$ \\
\hline Metropolitan & 103,001 & 10.4 & 1,970 & $\begin{array}{l}50 \\
50\end{array}$ & $\begin{array}{l}3.6 \\
2.9\end{array}$ \\
\hline PAIS & 432,499 & 17.4 & & & 5.5 \\
\hline
\end{tabular}

Source: Blanlot (1999)

Although the subsidy program has been improved over time, the goal of no family spending more than $5 \%$ of its income on water and sanitation services has not yet been achieved. At the aggregate level, the target has almost been reached: the after-subsidy bill for $15 \mathrm{~m}^{3}$ 
water consumption accounts on average for $5.5 \%$ of the mean income of a family in the lowest income decile nationwide. However, there is sharp regional disparity, and of course within each region not all first-decile families receive the average income. Reducing regional disparities should not be very complicated, but at the individual level it could be more difficult. One possibility would be to differentiate subsidy rates according to a family's SEF point score.

Table 2: Water consumption subsidy: beneficiaries and expenditure 1990-1998

\begin{tabular}{|c|c|c|c|c|c|}
\hline YEAR & $\begin{array}{l}\text { ESTIMATED } \\
\text { POTENTIAL } \\
\text { BENEFICIARIES }\end{array}$ & $\begin{array}{l}\text { ACTUAL } \\
\text { SUBSIDIES } \\
\text { GRANTED }\end{array}$ & $\begin{array}{l}\text { COVERAGE } \\
\%\end{array}$ & $\begin{array}{l}\text { EXPENDITURE } \\
\mathrm{Ch} \$ \text { million at } \\
\text { current prices }\end{array}$ & $\begin{array}{l}\text { EXPENDITURE } \\
\mathrm{Ch} \$ \text { million at } \\
1998 \text { prices }\end{array}$ \\
\hline 1990 & 424,625 & 21,842 & 5.1 & 3.5 & 7,980 \\
\hline 1991 & 424,625 & 177,719 & 41.9 & 263.0 & 503,893 \\
\hline 1992 & 441,040 & 315,901 & 71.6 & $2,255.7$ & $3,654,189$ \\
\hline 1993 & 443,068 & 351,925 & 79.4 & $4,437.2$ & $6,506,373$ \\
\hline 1994 & 454,038 & 389,712 & 85.8 & $7,129.8$ & $9,268,727$ \\
\hline 1995 & 461,508 & 399,205 & 86.5 & $9,305.8$ & $11,166,935$ \\
\hline 1996 & 466,508 & 442,524 & 94.6 & $12,053.5$ & $13,505,565$ \\
\hline 1997 & 466,508 & 443,953 & 95.2 & $14,339 ., 0$ & $15,055,950$ \\
\hline 1998 & 466,508 & & & $15,479.1 *$ & $15,479,065$ \\
\hline
\end{tabular}

Source: Ministry of Economics

*Allocated in national budget 


\section{National rural drinking water program}

This program, which began in the 1960s, is currently the responsibility of the Ministry of Public Works (MOP). It mainly finances the installation of potable water services in rural areas, although part of the funds are used to expand, improve and refurbish existing rural systems. Interested parties submit projects through their municipalities. The main requirement is to form a concentrated rural zone, which means grouping together more than 150 permanent residents with a density of over 15 dwellings per $\mathrm{km}$ of road. Projects are appraised using an established methodology, and approval is given to those with a positive NPV at discount rate of $12 \%$.

With the portfolio of approved projects, the MOP requests funding from the Finance Ministry, whose job it is to decide the amount to be allocated to each region and provide for this in the national budget. Once the annual budget as been approved by Congress, the MOP informs regional governments of the available funding and the list of projects approved. Each regional government selects which projects to execute, according to its own criteria and priorities, using up all the funds assigned. The MOP is responsible for executing the projects selected, for which purpose it contracts technical direction from the respective regional water company. The water company is paid between $12 \%$ and $15 \%$ of the value of the project for this service. Starting in 2000, following water company privatization, projects will be put out to tender among the different water companies, and eventually bidding could be opened up to other firms as well.

The Treasury keeps ownership of the civil works, but delegates their management to local agents, who have to form a management committee to determine the rate of charge, 
among other things. The consumption charge must at least finance the operating costs of the system, except for technical assistance, which is funded through the Program. The MOP outsources this to the water companies and oversees execution. By late 1998 there were 1,049 rural drinking water services catering to 1,318 localities, with a total of 202,734 installations benefiting 1,117,842 households. By the end of 2000 the aim is to achieve a coverage of $98 \%$ of the concentrated rural population, representing between $30 \%$ and $40 \%$ of the total rural population.

Table 3: National rural drinking water program

\begin{tabular}{|c|c|c|c|c|c|c|}
\hline \multirow[t]{2}{*}{ Year } & Budget & \multicolumn{2}{|l|}{ Expenditure } & \multirow{2}{*}{$\begin{array}{l}\text { Connections } \\
\text { installed }\end{array}$} & \multirow{2}{*}{$\begin{array}{l}\text { Localities } \\
\text { benefited }\end{array}$} & \multirow{2}{*}{$\begin{array}{l}\text { Coverage } \\
\%\end{array}$} \\
\hline & $\begin{array}{l}\mathrm{Ch} \$ \text { million } \\
\text { (current } \\
\text { prices) }\end{array}$ & $\begin{array}{l}\text { Ch\$ million } \\
\text { (current } \\
\text { prices) }\end{array}$ & $\begin{array}{l}\text { Ch\$ million } \\
\text { (Dec.1998 } \\
\text { prices) }\end{array}$ & & & \\
\hline 1994 & $2,048.4$ & $1,551.8$ & $2,060.8$ & 1,103 & 9 & 81 \\
\hline 1995 & $8,124.5$ & $7,113.5$ & $8,728.2$ & 5,434 & 38 & 82 \\
\hline 1996 & $10,254.7$ & $9,657.3$ & $11,049.5$ & 5,353 & 38 & 83 \\
\hline 1997 & $14,079.2$ & $13,454.6$ & $14,467.3$ & 9,215 & 79 & 90 \\
\hline 1998 & $20,787.2$ & $20,439.4$ & $20,835.3$ & 8,789 & 64 & 93 \\
\hline 1999 & $20,760.0$ & & & & & \\
\hline
\end{tabular}

Source: Ministry of Public Works

As table 3 shows, spending on the program grew tenfold between 1994 and 1998, which made it possible to increase the number of localities benefited by seven times. Part of the funds are spent on technical assistance, although the budget for 1999 stipulated that no more than $\mathrm{Ch} \$ 915.5$ million should be spent on this item, in other words less than $4.4 \%$ of the total budget. Ignoring the fact that part of the funds are spent on technical assistance and on refurbishing existing services, the average annual cost per mains connection varied in this period between $\mathrm{Ch} \$ 1.6$ and $\mathrm{Ch} \$ 2.4$ million, so the subsidy received per family is 
significant. On the other hand, the annual average number of main connections per project varied between 137 and 117, which shows that the program is reaching small localities.

In 1994, a program was set up to support the conservation of existing rural drinking water systems, as the Rural Drinking Water Program tends to focus on funding new systems. The aim of this new subsidy is to support the expansion, improvement and refurbishment of existing services, with funding for pre-investment studies as well as for the work itself. The corresponding regulations were approved in 1998, but funds have not yet been allocated from the national budget.

Publicizing this program will be the responsibility of the municipalities, which will have to foment citizen participation. Every year the MOP will prepare a list of projects, based on its own data and the needs put forward by rural communities using a form distributed by MOP. The latter will estimate the cost of each project as well as the contribution demanded of the community, since beneficiaries are expected to contribute part of the financing. The size of the contribution will depend on the socioeconomic situation of the community, as calculated by an established methodology. With this information, communities that decide to apply for the subsidy can do so through their respective municipalities.

The MOP will draw up a list of projects for each region. The annual budget prepared by the Finance Ministry and approved by Congress will contain the funds assigned to each region. In December each year, the MOP will send regional governments a list with evaluated projects that it is possible to finance, together with the amount of funding, and the contribution required from applicants. Regional Governments will select 
the projects to execute, taking into account their social return, the socioeconomic condition of the beneficiaries, the payment capacity of the community applying for the subsidy. 


\section{Rural Electrification Program}

Electricity coverage is almost $100 \%$ in urban zones, so government support in this sector has focused on rural areas. Subsidies are provided to finance self-generation projects, extensions of the distribution network and feasibility studies. The maximum subsidy is for an amount equal to the negative private NPV of the project, which means that beneficiaries and distribution companies are expected to contribute to a project's financing. In particular, beneficiaries are required to pay for the connection, the meter and domestic installation, which become their property. In 1994 the government set a goal of $100 \%$ electrification coverage among rural homes by the year 2005 , with an intermediate target of $75 \%$ by year 2000. For this purpose, resources were increased substantially as from 1995, when a new fund was set up specifically to subsidize rural electrification projects. Prior to this, projects were financed solely through the General Regional Development Fund (GRDF) administered by the Under-Secretariat for Regional Development in the Interior Ministry.

The GRDF allocates monies from the national budget to regional governments for the financing of investment projects in health, education, housing, electrification, etc. Projects financed from this source require prior approval from the Ministry of Planning (Mideplan), for which they need to be socially profitable but privately unprofitable, as measured by standard valuation methodology. The allocation of funds depends on regional needs and the total value of the investment projects the region has registered with the National Project Bank administered by Mideplan. Since funds allotted to regions are insufficient to cover all their investment needs, regional governments have to select the projects that in their view are of highest priority. In the GRDF program, rural electrification 
is in competition with other types of project. For this reason, the government created the Rural Electrification Program (REP), which operates in a similar way to the GRDF except that its funds are reserved for rural electrification projects.

Central government allocates REP funds to regional governments, taking into account variables such as the region's electrification deficit and the allocation of GRDF funds to rural electrification in previous years, thereby establishing a form of competition between regions. In the formula used to distribute REP funds among regions, variables are weighted as follows: the number of non-electrified homes, 50\%; the value of projects approved by Mideplan waiting to be financed, 15\%; the coverage shortfall below $75 \%$ : 20\%; GRDF funds allocated to rural electrification during the previous three years: $15 \%$. Regions are thus encouraged to prepare rural electrification projects and finance them with GRDF funds, in order to receive a greater REP allocation in subsequent years. In fact, the GRDF funds that regional governments assign to rural electrification have increased substantially since 1995 .

In 1995, along with the creation of the REP, the type of project eligible for funding was also broadened. Until that year, the GRDF only financed network extension projects serving households. As from 1995, however, projects could now also include the provision of street lighting, as well as supply productive activities and public services such as schools and health centers. Also included were self-generation projects in localities far from the concession areas of electricity companies. The evaluation methodology was altered to take account of these changes. The measurement of benefits includes non-residential users, and non-conventional energy sources are also evaluated for electric power generation (wind, 
solar panels, hydraulic and hybrid systems). In all cases the desired end product is the supply of 220 volts $\mathrm{AC}$ at $50 \mathrm{~Hz}$ frequency, 24 hours a day.

Central government publicizes the Rural Electrification Program (REP) at the national, regional and borough levels. It also hires consultants to work with regional governments in designing electrification strategies. The procedure for applying to the REP is as follows: the inhabitants of a locality without electricity supply organize themselves, prepare a list of potential users, and request the municipality in which they live to undertake an electrification project, alternatively the municipality itself may detect the corresponding need. The municipality, in turn, requests a technical project and budget, at no charge, from the distribution company, or else occasionally hires a consultant for this purpose. Municipalities collect the information needed to compute the project's private and social NPV, according to a standard methodology developed by Mideplan. The regional government then revises this evaluation.

By way of example we describe the methodology used to measure the benefits to residential consumers. It is measured in terms of consumer surplus, in other words as the area under the demand curve. The no-project price-consumption pair $\left(P_{0}, Q_{0}\right)$ is estimated as follows. The execution of rural electrification projects enables the population to cut down on consumption of candles, paraffin, batteries or gas, and also reduce the time spent purchasing such items. Estimates of these figures are converted into their equivalents in $\mathrm{kWh}$ per month (the consumption $Q_{0}$ ) and $\mathrm{Ch} \$$ per month (current spending on energy of households $\mathrm{G})$, respectively. The price $P_{0}$ is obtained dividing expenditure $(G)$ by consumption $\left(Q_{0}\right)$. 
The with-project pair $\left(P_{1}, Q_{1}\right)$ is determined in the following way. In principle, electricity requirements are estimated from consumption categories in rural localities that have electricity, where use has already stabilized (in other words, the community has had electricity without rationing for at least five years). However, these figures are modified with the specific situation of the locality concerned. In the case of a network extension, the price $P_{l}$ is equal to that applied in the nearest concession zone, plus surcharges for distance when consumption occurs outside a $20 \mathrm{~km}$ radius from the nodes of a trunk transmission line. In self-generation systems, the rate is agreed between the municipality and the service provider, and must at least cover the costs of operating, maintaining and managing the system.

The methodology further assumes constant price elasticity of demand. Thus energy consumption is given by $\mathrm{Q}=\mathrm{aP}^{\mathrm{e}}$, where $\mathrm{a}=\mathrm{Q}_{0} / \mathrm{P}^{\mathrm{e}}$, and :

$$
e=\frac{\operatorname{Ln}\left(Q_{0} / Q_{1}\right)}{\operatorname{Ln}\left(P_{0} / P_{1}\right)}
$$

In self-generation projects, applications have to describe the active institutions existing in the locality. This makes it possible to judge whether it is feasible for a cooperative or other organization from the community itself to operate and maintain the project; however, there tends to be a preference for the concession being held by the electricity distribution company corresponding to the area, due to the need for future extensions. Nonetheless, there are user cooperatives in charge of electrification projects, such as generation from biomass gasification on an island. There are also examples of distribution companies that have built self-generation projects using the State subsidy. 
With the funds provided by the central authorities, regional governments select the rural electrification projects to be subsidized and transfer the necessary funds to the municipalities. These usually award execution of the civil works to the distribution concession-holder in the area, but where there is more than one distributor capable of providing the service, execution of the civil works is put out to tender. The new equipment and networks are transferred to the distribution firms, which are then committed to operate, maintain and manage them for at least 30 years. In recent years, the REP has transferred about US\$129 million in assets to distribution companies in this way.

Table 4: Rural electrification program

(Ch\$ million December1998 prices)

\begin{tabular}{|l|l|l|l|l|l|}
\hline Year & $\begin{array}{l}\text { Homes } \\
\text { electrified }\end{array}$ & $\begin{array}{l}\text { Total } \\
\text { Subsidy }\end{array}$ & $\begin{array}{l}\text { Average } \\
\text { subsidy } \\
\text { household }\end{array}$ & $\begin{array}{l}\text { Subsidy as \% } \\
\text { po } \begin{array}{l}\text { Rural } \\
\text { investment }\end{array}\end{array}$ & $\begin{array}{l}\text { electricity } \\
\text { coverage \% }\end{array}$ \\
\hline 1992 & 8,442 & $4,402.6$ & 521.5 & 70.0 & 55 \\
\hline 1993 & 9,123 & $4,982.3$ & 546.1 & 70.0 & 57 \\
\hline 1994 & 8,370 & $3,525.9$ & 421.3 & 64.0 & 58 \\
\hline 1995 & 17,933 & $9,508.0$ & 530.2 & 63.0 & 62 \\
\hline 1996 & 19,053 & $11,123.6$ & 583.8 & 64.0 & 66 \\
\hline 1997 & 19,107 & $11,626.9$ & 608.5 & 62.0 & 70 \\
\hline 1998 & 20,427 & $13,446.5$ & 658.3 & 61.0 & 74 \\
\hline September 99 & 10,639 & $7,344.0$ & 690.3 & 61.0 & 75 \\
\hline \multicolumn{7}{|l|}{} & & & & \\
\hline Total & 113,094 & $65,959.8$ & $4,560.0$ & & \\
\hline
\end{tabular}

The incentive mechanism provided by the REP has had a considerable impact on rural electrification, although it actually only provides about a third of all rural electrification subsidies. Total subsidies provided by the REP and the GRDF together averaged approximately US\$ 24 million per year between 1995 and 1997, and about US\$ 
30 million in 1998; in earlier years subsidies totaled less than US\$ 10 million. The average number of households subsidized per year increased from 8,645 in 1992-94 to 19,130 in 1995-1998. Since the introduction of the REP, 113,090 rural homes have been electrified, increasing rural coverage from $57 \%$ in 1994 to $75 \%$ by September 1999. As a result, the aggregate target set for December 2000 was achieved 15 months early, although some regions still have a lower coverage (62\% in Regions X and XI), and there were still 140,786 rural households without electricity in September 1999.

The cost of the subsidy per household has risen, as it has steadily benefited more remote localities, growing from $\mathrm{Ch} \$ 520,000$ in 1992 to $\mathrm{Ch} \$ 690,000$ in 1999 at December 1998 prices; this situation ought to generate greater concern for costs. There are indications that the existing methodology overestimates the subsidies needed to attract distribution companies. Firstly, in places where there are projects already operating, demand has grown faster than the rate used to evaluate the projects, so the income flows have been underestimated. Secondly, in projects put out to tender, the successful bidder has usually sought a subsidy below the maximum allowable. This situation has led the authorities to establish various forms of yardstick competition, comparing unit costs where there is competition with places where there is none, or with those used in rate-setting processes. Another policy has been to negotiate the execution of a larger number of projects in exchange for a reduction in the subsidies sought. The official in charge of the REP program in the Xth Region estimates that the State saved about Ch\$ 3 million or $20 \%$ in that region, compared to the estimated subsidies, through the mechanisms described above.

In the XIth Region, civil works were put out to tender among other firms apart from electricity distributors. However, the problem with this is in deciding who will be 
responsible for maintaining the installations, as companies do not want to take responsibility for maintaining installations whose quality has not been under their control. Moreover, while this system might reduce the cost of the investment, the State has to take it on in full. One way of reducing costs could be to set up electrification plans of more than one year's duration, five years for example, which would allow better programming of electricity grids by planning all the civil works to be carried out over several years. This would avoid ending up with inefficiently designed networks. Apart from this, tendering larger-scale electrification programs would make it possible to attract other operators besides the local distribution company.

In self-generation projects, the government has tried to promote the use of clean technologies, in particular promoting solar-panel solutions for localities in the north of the country and hybrid wind-gasoline systems in southern regions. In 1998 two large-scale projects were studied, the first of which is a project in the IVth Region to provide electric power to 6,000 households via solar panels. A portfolio of wind-powered projects was also designed to supply 3,500 homes located in the 36 islands that make up the Chiloé archipelago in the Xth region. These two projects together amount to an investment of nearly US\$ 18 million. Previously, the electricity distribution company in the IXth region had been awarded two hybrid generation projects using wind and gasoline, but these have not worked very well mainly because of the high maintenance costs involved. In fact, the company has now interconnected one of the two locations to the grid. 


\section{Telecommunications Development Fund ${ }^{8}$}

The situation in the telecom sector is different from those of the water and electricity services. Telephone density nationwide is relatively low -21 lines per 100 inhabitants in 1999, which clearly shows that still there are vast sectors of the population with limited or no access to telecom services. A telephone in every home is, for the moment, a distant goal, although it is realistic to consider universal access, for which reason the government created the Telecommunications Development Fund (TDF) in 1994. Chilean telecom legislation defines the TDF mission as to promote the installation of public telephones, available 24 hours a day, in low-income neighborhoods and remote areas, i.e. areas of low telephone density. Broadly speaking, the government subsidizes projects whose social rate of return is positive, but which are not profitable from the private point of view. The maximum subsidy is equal to the lesser of the negative private NPV of the project and the estimated cost of the investment.

The Under-Secretariat for Telecommunications (Subtel), in conjunction with regional governments and municipalities, carries out an annual campaign to publicize the program. Potential beneficiaries - individuals or community organizations - submit applications to their local authorities. The application includes the name of the locality, the number of inhabitants and the distance to the nearest public telephone. Municipalities and regional governments make an initial selection, bearing in mind that the project should favor low-income people, before dispatching the application to Subtel. The latter checks the information in each application and hires consultants to prepare a list of technical projects.

\footnotetext{
${ }^{8}$ This section builds on a report jointly written with Daniel Hojman (Hojman and Serra, 1999)-
} 
The consultants' job consists of grouping localities together (average 36) and defining a technical solution to minimize the investment cost. A basic theoretical engineering model is used to choose the solution, based on parameters such as the geographic dispersion of the phones to be installed, population density, the topography of the land, and the distance to the nearest interconnection center. The main output of this stage of the process is an estimate of the investment cost for each project.

Subtel then computes the social and private NPV of each project, using a standard methodology. For each locality, the social benefit corresponds to the consumers' surplus, i.e. the area below the demand curve. In the with-project situation, price corresponds to the regulated tariff, and traffic is estimated from empirical data in places that have similar conditions. ${ }^{9}$ Initially, estimated traffic was calculated by assuming that households spent $8 \%$ of their income on communications services and that all households belonged to the second lowest quintile. Since 1999, however, traffic has been estimated using parameters obtained from a regression on actual traffic in a sample of public rural phones subsidized by the TDF. Statistical results show that per-capita traffic declines with the number of inhabitants. The figure used in the social and private evaluation of projects, for the monthly number of calls per phone, is equal to 2.2 times the number of inhabitants when the population is below 150. Otherwise, estimated monthly traffic is given by the expression $148 \mathrm{~L}^{0,16}$, where $\mathrm{L}$ denotes the population. As the tariff is fixed in real terms and equal for all rural public phones, its effect on demand could not be isolated. But, for the same reason, it is not required for estimating demand in new localities. In the no-project situation, the price corresponds to the cost (including the value of time) of traveling to the nearest 
existing phone, plus the cost of the phone call itself. The demand curve is completed using price elasticities estimated in 1994, a relatively dated estimate given the changes experienced by the sector in the last years.

Table 5: Subsidies allocated per company 1995-1999

\begin{tabular}{|l|l|l|l|l|}
\hline \multirow{2}{*}{ FIRM } & \multicolumn{2}{l|}{ SUBSIDY ALLOCATED } & \multicolumn{2}{l|}{ PHONES ALLOCATED } \\
\cline { 2 - 5 } & Thousand Ch\$ & $\mathbf{\%}$ & Number & $\%$ \\
\hline CTC & $2,642,407$ & 28.1 & 1,880 & 31.8 \\
\hline CTR & $1,481,186$ & 15.8 & 1,843 & 31.2 \\
\hline GENEVA & 190,000 & 2.0 & 153 & 2.6 \\
\hline GVT & $3,421,843$ & 36.4 & 1,737 & 29.4 \\
\hline MEGACOM & $1,655.633$ & 17.6 & 303 & 5.1 \\
\hline TOTAL & $\mathbf{9 , 3 9 1 , 0 7 0}$ & $\mathbf{1 0 0 . 0}$ & $\mathbf{5 , 9 1 6}$ & $\mathbf{1 0 0 . 0}$ \\
\hline
\end{tabular}

Source: Memoria 1999, Fondo de Desarrollo para las Telecomunicaciones, Memoria 1999, Subtel.

The government allocates resources to the TDF through the annual public-sector budget. Then Subtel sets the priorities and selects the highest-ranking projects until available funds are exhausted. Each selected project is then put out to public tender and awarded to the bidder seeking the smallest subsidy. The technology chosen by the successful bidder does not have to match that used in computing the maximum subsidy. Usually, competition between bidders determines the actual subsidy, and the maximum subsidy only serves as a cap in cases when there is only one bidder. For this reason, the authorities have been especially concerned to ensure that several companies bid for each project. In the first year only two companies entered bids: CTC and CTR. But in subsequent years a further three companies started bidding. Table 5 shows the participation

\footnotetext{
${ }^{9}$ The regulated tariff is the same for all public rural phones and is indexed to the cost of living. Currently 100 pesos for 84 seconds.
} 
of each of the five companies; in some projects, however, there has been just one bidder, or even none at all.

The method used to estimate investment costs is quite crude. For one thing, they are estimated by using a theoretical model; and secondly, the technical project designed by the consultant does not take existing infrastructure into account, so investment estimates tend to be biased upwards. ${ }^{10}$ The private evaluation of the project does not include income earned by the concession holder from installing new lines, whereas both existing and new operators have extended their rural networks on the basis of projects financed by the TDF. This reinforces the idea that the maximum subsidy is likely to be an upper bound to the rate needed to make the investment privately profitable. However, a more rigorous and costlier analysis is not justified for two reasons: firstly, the average subsidy granted per phone (US\$ $3,000)$ is relatively low, and secondly, the actual subsidy is usually determined by competition between the bidders for the project.

Social profitability is likely to be underestimated, since investment costs are overestimated and social benefits are underestimated, because the methodology used fails to consider either the benefits from installing additional lines or the gains to existing subscribers. Most importantly, the social evaluation used excludes the value society assigns to connecting isolated areas to telecom networks, possibly because, in standard cost-benefit analyses, it is difficult to include the social gains arising from mitigating the isolation of remote locations where telephony is a basic need.

\footnotetext{
${ }^{10}$ On the other hand, companies receive the subsidies, which are expressed in nominal currency,once the telephone is operating, on average two years after the subsidy is awarded. Calculation of the subsidy considers neither inflation nor the cost of capital.
} 
A related issue involved an imprecise definition of public access to a telephone. It was not until 1999 that Subtel defined a precise aim for the Telecommunications Development Fund, namely to install public pay-phones in all rural localities with over 60 inhabitants, which are more than $3 \mathrm{~km}$ or 30 minutes away from nearest existing public phone. Participation by local authorities has increased not only in terms of refining the information used in the social and private project evaluation, but also in deciding which projects to finance, where local agents have better knowledge of needs in their particular area. In fact, in subsidy programs related to other utilities, it is the regional authorities that decide which projects are carried out. Only in telecommunications has there been a more centralized and technocratic approach, which has both advantages and limitations.

The Fund has dramatically increased the access of the rural population to telecommunications; since its creation it has granted subsidies to install public phones in 5,916 rural localities serving more than 2 million inhabitants. Taking projects approved in 1998 into account, $80 \%$ of the rural population will have access to public phones by mid 2001, compared to just $10 \%$ in 1995 . The total cost of the subsidy program has been quite low: in its five years of operation the Fund has compromised subsidies totaling US\$ 19,7 million (US\$ 2.0 million in 1995, US\$ 0.9 million in 1996, US\$ 7,2 million in 1997, US\$ 5,4 million in 1998, and US\$ 4,2 million in 1999). Actual expenditure has been much lower than the amount budgeted for by the government, since firms requested $52,4 \%$ of the maximum subsidy on average during the period 1995-1999, and the sum total of maximum subsidies on projects put out to public tender cannot exceed the budget. 
Table 6: Subsidies allocated per year and localty

\begin{tabular}{|c|c|c|c|c|c|c|}
\hline Year & $\begin{array}{c}\text { Phones } \\
\text { allocated }\end{array}$ & $\begin{array}{c}\text { Thousand } \\
\text { inhabitants } \\
\text { benefited }\end{array}$ & $\begin{array}{c}\text { Available } \\
\text { Funds in } \\
\text { current } \\
\text { million CH\$ }\end{array}$ & $\begin{array}{c}\text { Subsidies } \\
\text { granted in } \\
\text { current } \\
\text { million Ch\$ }\end{array}$ & $\begin{array}{c}\text { Average } \\
\text { subsidy per } \\
\text { localty in } \\
\text { current } \$\end{array}$ & $\begin{array}{c}\text { Subsidies } \\
\text { granted as \% } \\
\text { of available } \\
\text { funds }\end{array}$ \\
\hline 1995 & 726 & 240 & 1,728 & 836 & & \\
\hline 1996 & 1,632 & 761 & 3,555 & 371 & & \\
\hline 1997 & 2,146 & 772 & 4,849 & 3,396 & & \\
\hline 1998 & 858 & 227 & 3,200 & 2,545 & & \\
\hline 1999 & 554 & 154 & 2,300 & 2,243 & & \\
\hline & & & & & & \\
\hline Total & 5,916 & 2,157 & 15,632 & 9,391 & & \\
\hline
\end{tabular}

Source: Memoria 1999, Fondo de Desarrollo para las Telecomunicaciones, Memoria 1999, Subtel.

The subsidy per installed rural telephone is about US\$ 3,000, compared to the US\$ 12,000 spent before the Fund came into existence. The main explanation for lower subsidies than before is the introduction of competitive bidding, although the figure is rising (US\$ 8,000 in 1999) as more isolated projects - with fewer collateral benefits - are put to tender. In the period 1995-1997 firms thought about $40 \%$ of the maximum subsidy on average. But this figure is raising: in 1998 firms sought 62\% and 75\% in 1999. Subsidies financed about $28 \%$ of estimated total investment in 1995-97, but the figure had jumped to $49 \%$ by 1998 . The cost of administrating the Fund has been low, accounting for $1 \%$ of total expenditure.

Although the program has been successful, giving access to public phones to about $80 \%$ of the rural population at relatively low cost, it has not been trouble-free. One major problem is that it can take up to 3 years to install a phone. The bidding process lasts a whole year and then concession-holders have up to 24 months to install the corresponding equipment. The problem could be mitigated if the installation date were to be included as a bidding variable, rewarding bidders not only for seeking the lowest subsidy but also for installing the phones in the shortest time. The formula for selecting the winning bid should 
include the difference in social benefit from installing a public phone today, compared to one that will be in service in 24 months' time. Another suggestion for cutting installation time is to prepare a list of localities that satisfy the eligibility requirements. The existence of a list would do away with the need for a yearly publicity and applications program. Given the delay between the application for a public telephone and its installation, it would be useful to inform beneficiaries of the contracted installation date and keep them up to date on the state of progress. This information is not currently provided, these days which is a cause of great dissatisfaction among beneficiaries.

Apart from this, the deadline for starting services has been exceeded in some cases, and Subtel had to fine 19 projects in $1998 .^{11}$ By the end of 1998 only 1,110 units had been installed - just $65 \%$ of the phones due by that date. There are two reasons for the delay: firstly, firms underestimated the geographic and weather challenges in certain remote areas; and secondly, the parent company of one of the firms participating in the public tenders went through serious financial difficulties; as a result that firm received 15 out of the 19 fines. Sanctions for delay are quite low, with a maximum penalty per phone for delays of over a year set at 1 UTM (Ch\$26,600 in January 2000). The number of arrears, however, diminished significantly in $1999 .{ }^{12}$ Of the 4,390 phones due, $92 \%$ was installed by the end of the year. Moreover, 211 phones due in year 2,000 were operating by the end of 1999.

\footnotetext{
${ }^{11}$ Subtel imputed 28 projects, of which 19 were fined, 5 were only admonished, and in the remaining cases a resolution is still pending.

${ }^{12}$ In many cases the delay was due to aspects beyond the control of the franchisee, such as an erroneous identification of the locality.
} 
Table 7: Number of phones due and installed by December 31, 1999

\begin{tabular}{|l|l|l|l|}
\hline Year & Phones due & Phones installed & Percentage installed \\
\hline 1997 & 265 & 265 & 100 \\
\hline 1998 & 1,551 & 1,436 & 92,6 \\
\hline 1999 & 2,574 & 2,350 & 91.3 \\
\hline 2000 & 1,078 & 211 & 19,6 \\
\hline 2001 & 448 & & \\
\hline Total & 5,916 & 4,262 & 72,0 \\
\hline
\end{tabular}

Source: Memoria 1999, Fondo de Desarrollo para las Telecomunicaciones, Memoria 1999, Subtel.

A second problem has been the quality of the service - particularly its reliability. The successful bidder takes on the commitment to maintain the public phone for ten years, which is not a minor issue since some of the phones are in remote areas, and maintenance and billing costs are quite high. There are indications that service quality, especially among phones located in isolated areas, is not always the best: hence the need to monitor service quality, especially its continuity, in order to guarantee fulfillment of the standards established in the regulations. One way of doing this would be through user surveys. Local authorities are closer to the subsidy beneficiaries and so in the best position to carry out such surveys; municipalities should therefore be active in monitoring public phones.

In some rural phone concessions the franchise-holder delegates responsibility for collecting payments to an administrator. Despite being public phones, they operate like private telephones in terms of billing, which raises two problems. Firstly, it makes it hard for the administrator to charge for long-distance calls, since invoices arrive with a delay. Secondly, if the administrator fails to pay the invoices on time, the service is cut off, thereby harming the entire community. Since 1999 it has been obligatory to install coinoperated phones, but this does not solve the problem of the telephones already installed. Another problem is that coin-operated telephones sometimes break down because the 
concessionaire fails to collect accumulated coins in a timely fashion. A solution to this would be to use pre-paid cards.

The Fund can also subsidize phone projects in urban zones, although despite the scarcity of public pay phones in poor urban areas, no urban project has yet been subsidized. The explanation for this is that the methodology used for computing the maximum subsidy does not consider the replacement cost of vandalized public telephones - probably the major cost in public pay phones. As a result, public phones located in open spaces are not a reliable communication system, and the government is considering a review of its methodology for granting subsidies.

One alternative would be to install phones in small shops or even in houses. However, it would be difficult to keep these open 365 days a year, 24 hours a day, unless a substantially higher payment than the $15 \%$ of revenue collected, used in the project appraisal, is considered. Another solution would be to subsidize the installation of residential phones, and even subsidize the fixed part of the bill, which amounts to about US\$ 10 per month. In this way, subsidized consumers would still face the marginal costs of calls made. Mobile phones that use prepaid-cards have become quite popular among poor people, where for the purchase of a US\$ 40 card the customer receives cellular phone for free. Since mobile phone pricing applies the principle of calling-party-pays, a mobile phone owner can receive any number of incoming calls free of charge, but the cost of outgoing calls is relatively high at US $\varnothing 20$ per minute. ${ }^{13}$ In a public pay phone, US $\varnothing 9$ buys a threeminute call, so prepaid-card mobile telephony is expensive in per-minute terms, but quite 
useful for emergencies.

\footnotetext{
${ }^{13}$ The number of mobile phones increased from 410,000 in December 1997 to 2,105,000 in November 1999, after "calling-party-pays" pricing was established and two new mobile operators entered the market, cutting prices by half.
} 


\section{Analysis of Chilean utility subsidies}

In the 1980s new regulatory frameworks were introduced for all utilities in anticipation of their privatization, a cornerstone of which is cost-reflecting pricing for services provided under monopolistic conditions. The new rate-setting schemes have two aims: to allow firms to self-finance and encourage them to be efficient, with rates based on the long-term marginal costs of simulated efficient firms. The regulatory amendment meant raising charges when these did not cover the costs of providing the service, as in the case of potable water, or rebalancing them when there were cross subsidies, such as from longdistance to local telephony. The geographic cross subsidies that pervaded all utilities were also eliminated, and relatively cost-homogeneous pricing zones were defined.

The main reason for introducing cost reflective-rates was to eliminate economic inefficiencies; from a formal static point of view the price should reflect the marginal cost of providing the service. The elimination of cross subsidies had the additional benefit of facilitating competition in services where it was possible for this to emerge. For example, the cross subsidies in telephony operated through the access charge to the local network paid on long-distance calls, which was several times higher than the actual cost of providing access. When the multicarrier system came into operation in 1994, these charges were reduced substantially, although insufficiently. For that reason in the 1999 rate-setting process they were reduced by an additional $62.7 \%$ on national and international outgoing calls. In the case of incoming international traffic, the charge was reduced by $97.5 \%$ in normal hours and by $99.6 \%$ in off-peak periods. High access charges put competition in doubt during the period 1994-1999, and many long-distance operators went through serious financial difficulties. The local telephony companies, which were allowed to operate in the 
long-distance market through subsidiaries, had incentives to charge rates below cost on long-distance calls, since by lowering rates long-distance traffic would increase and the companies would benefit from the higher revenue arising from access charges to the local network, a reward that the other long-distance companies did not have.

The Chilean experience shows that competition produces a substantial drop in prices on services that were previously regulated or had entry barriers, thereby eliminating a significant deadweight loss. Once the long-distance service was deregulated in 1994, call prices fell by over $50 \%$ ( $80 \%$ in the case of large clients), and when the mobile telephony PCS system came into operation in 1998, increasing the number of mobil phone operators from two to four, tariffs fell by approximately 50\%. Energy prices at the generation level, where there is some degree of competition, fell by more than $50 \%$ between 1988 and 1998. ${ }^{14}$ However, the price of electricity for residential clients dropped by only $25 \%$ in this same period, which is minimal considering that apart from the fall in energy prices, distribution losses were cut from $19 \%$ to $8 \%$, and labor productivity increased from 393 clients per worker to 703 in 1997 in the largest distribution company. This situation is explained by the fact that electricity distribution companies are regulated regional monopolies. The figures illustrate the importance of facilitating the entry of new operators into previously monopoly markets.

Current utility charges in Chile consist of a monthly standing charge and a variable rate. The latter distinguishes between peak and off-peak periods. Regulated prices are reviewed every four years in the case of electricity distribution, or every five years in local

\footnotetext{
${ }^{14}$ This is explained by the fall in prices of the fuels used in power plants that determine marginal prices (namely the arrival of natural gas from Argentina), or greater use of installed power, and the passing on to consumers of productivity gains.
} 
telephony and water and sewerage. In the intervening period they are adjusted in line with an inflation index relevant to the sector. Current charges for residential consumers in Santiago are as follows. The local telephony standing charge is $\mathrm{Ch} \$ 5.356$ per month, with a variable rate of $\mathrm{Ch} \$ 16.3$ per minute during peak hours and $\mathrm{Ch} \$ 2.7$ in off-peak hours. Peak hours run from 8 am. till 8 pm. on weekdays and from 8 am. to $2 \mathrm{pm}$. on Saturdays. In water services the monthly fixed charge is $\mathrm{Ch} \$ 882$, the variable sewerage charge is $\mathrm{Ch} \$ 51$ per $\mathrm{m}^{3}$, and the variable drinkable water charge is $\mathrm{Ch} \$ 133.3$ per $\mathrm{m}^{3}$. Summertime consumption of drinkable water (December through March) in excess of average consumption over the previous 12 months pays $\mathrm{Ch} \$ 369.1$ per $\mathrm{m}^{3}$. A similar approach was adopted for electricity services: the pricing system consists of a fixed monthly charge of $\mathrm{Ch} \$ 692$ and a variable rate of $\mathrm{Ch} \$ 39.3$ per $\mathrm{kWh}$. Consumers pay $\mathrm{Ch} \$ 72.7$ per $\mathrm{kWh}$ for their consumption in peak (winter) months in excess of their average consumption over the preceding 12 months.

It is common for public services to be priced at marginal cost, with the difference between marginal and average cost being covered by a fixed charge, equal for all users. Marginal cost pricing in a two-part tariff has been criticized because the fixed part is essentially a regressive head tax (Feldstein, 1972). Moreover, cost-reflecting two-part tariffs are not always efficient. If enough consumers decide to disconnect from the service when the fixed charges rises, it might be more efficient to maintain a low charge (GómezLobo, 1996). The social loss arising from excluding consumers from a market through the fixed charge is equal to the surplus they would have perceived, less avoidable costs.

Fixed costs in Chile are generally not significant, and mainly correspond to meter reading and billing - i.e. unavoidable costs. The exception is in local telephony, where the fixed charge is not insignificant. The authorities in this sector claim that the standing charge 
represents the cost of the line that runs from the house to the switching exchange, for which reason it is also unavoidable. If this is the case, a rebalancing of rates involving a lower fixed charge and a higher variable rate would mean cross subsidies from people that use the telephone for more minutes to those who use it less; the phone companies would give a worse service to the latter, who would also tend to be the most poor. Something similar would occur if there was a fixed charge differentiated by income level or some other variable that did not correspond to objective differences in the cost of providing the service. In addition, having the consumer pay for the use of the external network facilitates competition: any service that does not require the switching service from the local telephony company could use the external network without paying for it, except for the rent of space in the switching exchange to install the equipment to channel the calls.

Cross subsidies do not always achieve their object of favoring the most poor. The cross subsidy from long-distance to basic telephony was premised on the idea that local telephony was more important than long-distance phone services in the consumption basket of poorer people. However, as there was no obligation to provide the service, telephone companies gave priority to installing telephones for higher income people likely to generate greater long-distance traffic. In the mid-1980s the waiting list for basic telephony stood at over $40 \%$ of all lines in service; and installation of a phone line could take more than 10 years, so the waiting list did not reflect real potential demand. In fact between 1987, the year in which rate rebalancing began, and 1999, the number of lines multiplied nearly sixfold. It also has to be remembered that the elimination of cross subsidies benefits the most poor when the fall in prices resulting from greater competition offsets the initial rebalancing of rates. 
How did the new pricing systems affect the poorest population sectors? As a result of rate rebalancing in telecommunications, the local phone bill for an average family rose from US\$ 9.3 in 1988 to US \$25.1 in $1998 .^{15}$ However, this situation did not affect the poor, because in fact they did not have access to local telephony. The change in the regulatory system has allowed many more families access to basic telephony. Moreover, improved regulation and greater competition in fixed telephony should reduce the effect of the initial rebalancing on prices. The cost of electricity has fallen, although not enough because of a lack of competition in the distribution segment. Regional rebalancing did affect small communities, where rates increased because of higher distribution costs.

Increases in drinking water charges clearly affected all consumers. The impact was also greatest in areas where rates rose most because of higher production costs. As a result, it was essential in this case to create a consumption subsidy. Long-run marginal cost pricing in rural areas, on the other hand, would mean prices that were prohibitive for rural inhabitants, given the substantial economies of density that exist in public services. For this reason, it was decided to subsidize investment so users would at least pay operating costs.

All subsidies, however, share two related characteristics: an emphasis on economic efficiency and targeting on the poor. The main reason for targeting subsidies is to reduce financial requirements. Taxes distort the economy, and the corresponding dead-weight loss grows more than proportionally with tax rates. Reducing the financial requirement by targeting the subsidy on the poor has a direct benefit. On the other hand, targeting extremes also has disadvantages, one of which is the possible lack of protection for families who are not poor enough to be eligible for the benefit. The second is that when they lose all benefit 
by reaching a given level of income, efforts to earn more income are discouraged. The consumption subsidy for drinking water is granted to the $20 \%$ poorest of the population, so those who do not fall in this category do not receive any help, although their income might actually be only slightly more than that of families that do receive it. If the subsidy were implemented such that no family spends more than $5 \%$ of their income on water services, this problem would be resolved.

There is a great concern for efficiency in subsidy design. For that reason, investment projects are subsidized if they yield a positive social return, and a criterion used for prioritizing projects has been the social NPV per peso of subsidy. The aim has also been for users to perceive the opportunity cost of the service at the margin, which means that rates continue to be cost reflecting, although only with respect to operating costs. For this reason, preference has been given to subsidizing investment, and, in the case of the consumption subsidy for drinking water services, the amount subsidized has a limit above which families pay the normal price. When families exceed this limit, as happens in most cases, they face the real cost of the service, so providing the same amount of subsidy in lump-sum form would have had the same result.

Whenever possible, investments in rural infrastructure are put out to tender among different operators, thereby obtaining the benefits of competition for the field between different operators. In telecommunications the tendering of projects has made it possible to substantially reduce the amount of subsidy granted, compared to the initial estimate by the authority. In electricity, in areas where two distributing companies overlap and projects have been put out to tender, the subsidy required has turned out less than estimated. In the drinking-water sector, investments so far have been carried out by publicly owned water 
companies. However as these are being privatized, the execution of rural infrastructure works will also begin to be put out to tender.

Subsidizing only those investment projects whose social return is positive is an appropriate criterion. However, the method of evaluation used in Chile only measures the benefit of the project to those directly involved, without considering its effect on the utility derived by society from the fact that rural inhabitants have access to utilities, or the various externalities that exist. The social benefit of the project is measured as the consumer surplus perceived by beneficiaries, while the resources used by the project, valued at social prices, constitute the project's social costs. ${ }^{16}$

The program that subsidizes investments in rural telephony used to prioritize projects according to the quotient between the social NPV and the required subsidy. As a result, it tended to benefit localities that were less isolated, because in more distant areas investment is more costly and population density is lower. Accordingly, remote localities were seldom selected for subsidy, and the goal of connecting the most isolated zones was not being fulfilled. As from 1999, the authorities changed policy by clearly defining the objective of bringing the service to localities of over 60 inhabitants and more than $3 \mathrm{~km}$ or 30 minutes distance from the nearest public telephone. Thus, although the social evaluation continues to be carried out, the program now has a more precise objective. Moreover, funds were set aside for localities that are cut off for part of the year.

Another characteristic of Chilean utility subsidies is that usually it is the potential beneficiaries who initiate the process by filling out an application form. This stems from a

\footnotetext{
${ }^{16}$ Strictly speaking the exact measure of the change in welfare is the compensating variation, but consumer surplus has been shown to be a good approximation to this.
} 
desire for citizens to participate in the programs, (as well as helping to target subsidies). However, this does not always work adequately, since the application process may be complex for the poorest people. Indeed, in the case of drinking water it was necessary to allow the water companies to make applications on behalf of their users. In the case of rural investment subsidies, the granting of subsidies in a more planned way would reduce costs, by making it possible to expand networks in a more rational manner. Perhaps the most appropriate solution is a combination of these two strategies. 


\section{Concluding remarks}

In Chile, cross subsidies have been virtually eliminated, and the existing subsidies are funded from the national budget. This has facilitated competition in some public services. Prices have fallen substantially in services where new operators have entered, which, as in other countries, shows that regulation is a poor substitute for competition. The decision to eliminate cross subsidies would therefore seem appropriate.

The Chilean experience also shows that is possible to design direct subsidies at a relatively small cost for the state, such as occurs with drinking water. For this purpose, subsidies need to be targeted on the most poor, although care needs to taken to avoid leaving other needy sectors unprotected. The public tendering of rural infrastructure investments, whenever feasible, has also made it possible to substantially reduce the need for public financing.

Another lesson from the Chilean experience is that it is possible to design subsidies that do not cause deadweigh losses, by making sure beneficiaries perceive the marginal cost of providing the service. It may be important to distinguish between rural and urban zones: in the former it is advisable to introduce consumption subsidies, with an upper limit on the amount subsidized. In this way, when the family consumes over the subsidized amount, it perceives at the margin the total cost of providing the service. In rural areas, where there is no infrastructure, investment needs to be subsidized. In this case users do not pay the longrun marginal cost, but the rate charged at least covers the short-run marginal cost. Rural utility charges are therefore required to cover the operating costs of the system.

Lastly, it is important to reiterate that the evaluation of subsidies must take account 
of the value society places on providing the most poor with access to public services that are considered basic for existence, as well as special regard for the needs of consumers living in rural areas. 


\section{References}

Alé, Jorge, 1990, "Estado Empresario y y Privatización en Chile," Universidad André Bello.

Blanlot, Vivian, 1999, "Evaluación y análisis de la evolución de las tarifas y subsidios y proposición para su adecuación al nuevo marco legal sanitario," report prepared for the Economy Ministry, Santiago, Chile.

Doble, Michael, Eleni Markou and Catherine Waddams Price, 1998, "Utility Regulation: Fairness for All, Responses to the Government's Green Paper," Centre for Management under Regulation Research Paper 98/4, University of Warwick.

Feldstein, Martin, 1972, "Equity and Efficiency in Public Sector Pricing: The optimal twopart Tariff," Quarterly Journal of Economics LXXXVI, 175-187, May.

Gómez-Lobo, Andrés, 1996, "The Welfare Consequences of Tariff Rebalancing in the Domestic Gas Market," Fiscal Studies 17: 49-65.

Harberger, 1978, "On the Use of Distributional Weighs in Social Cost-Benefit Analysis," Journal of Political Economy 86: S87-S120.

Hojman, Daniel and Pablo Serra, 1999, "Evaluación del Fondo de las Telecomunicaciones," Departamento de Ingeniería Industrial, Universidad de Chile, report prepared for Subtel.

Mideplan, 1999, "Antecedentes Administrativos, Operativos y Legales del Subsidio al Pago del Consumo de Agua Potable Servicios de Alcantarillado de Aguas servidas," Documentos MIDEPLAN, Santiago, Chile.

Waddams Price, Catherine, 1999, "Gas: Regulatory Response to Social Needs," Lecture presented in the IX IEA/LBS Regulation Series. 